\title{
PEMBINAAN ANTI KORUPSI DALAM KELUARGA KRISTEN DAN MUSLIM DI KOTA AMBON
}

\author{
Resa Dandirwalu \\ Universitas Kristen Indonesia Maluku, \\ Jl. Ot Pattimaipauw, Nusaniwe, Kota Ambon, Maluku, Indonesia. \\ E-mail: reza_villa@yahoo.com
}

\begin{abstract}
This research focuses on the method of anti-corruption practiced by the Christians and Moslems family in Ambon, using qualitative analysis. The result shows that the cultivating method of anti-corruption which is used in the Christians and Moslems family in Ambon is still giving advice only. I suggest the reciprocal method as an alternative for the Christians and Moslems family in Ambon to cultivate the anti-corruption. There some steps of the reciprocal process, i.e., parents firstly give the understanding to the children, they then can make their questions in a dialog. The children will be given an opportunity to identify the corruption problem, and the new question will arise and then produce an idea that can be developed and practiced. Both parents and children finally are asked to keep away from the corruption. It will be one of the solutions to the Christians and Moslems family to avoid the corruption.
\end{abstract}

\section{Keywords:}

Corruption; prevention; Christians; Moslems; reciprocal

\begin{abstract}
Abstrak
Penelitian ini memfokuskan pada metode pembinaan anti korupsi yang dipraktikkan keluarga Kristen dan Muslim di Kota Ambon. Melalui analisis kualitatif, hasil kajian memperlihatkan bahwa metode pembinaan anti korupsi dalam keluarga Kristen dan Muslim di Kota Ambon masih mempergunakan metode nasehat. Penulis mengajukan pentingnya metode alternatif berupa metode pembinaan anti korupsi yang bersifat timbal balik (reciprocal) antara orang tua dan anak. Inti metode tersebut adalah orang tua memberikan pengetahuan disertai pendampingan kepada anak, sehingga anak bisa membuat pertanyaan untuk dijelaskan melalui proses dialog. Agar evaluasi bisa terjadi, anak diberikan kesempatan untuk mengidentifikasikan persoalan korupsi. Pertanyaan baru dibuat, agar menghasilkan ide/konsep bersama untuk dikembangkan dan dipraktikan. Melalui pendekatan ini, keluarga Kristen dan Muslim di Ambon diharapkan bisa terbebas dari perilaku korupsi.
\end{abstract}

Kata Kunci:

Korupsi; pencegahan; Kristen; Muslim; timbal balik.

DOI: $10.15575 / \mathrm{jw} . v 3 \mathrm{i} 1.1334$

Received: May 2017; Accepted: March 2018; Published: August 2018 


\section{A. PENDAHULUAN}

Indonesia telah mengalami perubahan penting selama hampir dua dekade terakhir. Dari sebuah negara paling represif dan tersentralisasi secara politik, menjadi salah satu negara paling demokratis dan terdesentralisasi dengan baik. Meski demikian, berbagai hambatan terus membayangi penegakan hukum di Indonesia, khususnya secara konsisten Indonesia masih termasuk salah satu negara yang termasuk urutan tertinggi korupsi di dunia.

Salah satu wilayah dengan tingkat korupsi cukup tinggi di Indonesia adalah Maluku. Bertolak dari informasi media elektronik dan media cetak, dilaporkan bahwa kasus korupsi mewabah khususnya di Kota Ambon. Kasuskasus korupsi tersebut antara lain: kasus korupsi uang senilai Rp. 15 milyar, kasus korupsi proyek petakan sawah tahun 20072008 bernilai milyaran rupiah di Kabupaten Seram Bagian Timur (SBT), kasus korupsi proyek Pengembangan Usaha Mina Pedesaan (PUMP) tahun 2012 senilai Rp 600 juta, kasus korupsi proyek pencetakan sawah baru tahun anggaran 2013 senilai Rp.11,8 milyar, korupsi dana asuransi anggota DPRD Kabupaten Malra periode 1999-2004, kasus korupsi dana block grand tahun 2012 senilai Rp 9 milyar, kasus korupsi dana asuransi DPRD Kabupaten Maluku Tenggara. $^{2}$

Dalam lingkup Kota Ambon, beberapa kasus korupsi juga terjadi seperti yang tercatat dalam kasus korupsi proyek MCK di Desa Nania dan Galala Kota Ambon oleh Jacob Waas dan Paulus Sohuwat, kasus korupsi lahan tempat pemakaman umum (TPU) Gunung Nona, Kota Ambon, senilai Rp1,2 miliar, oleh Dr. J. M. Papilaya, M.Si (Wali Kota Ambon Periode tahun 2001-2006 dan 2006-2011) dan kasus korupsi pengadaan mobil penyuluhan Dinas Kelautan dan Perikanan (DKP) Kota Ambon, yang

\footnotetext{
1 Simon Butt, Corruption and Law in Indonesia (London and New York: Routledge, 2012), 1, https://doi.org/10.4324/9780203584729.

2 Sentra Informasi dan Data Untuk Anti Korupsi, "Korupsi Di Provinsi Maluku" (diakses tanggal 15 Maret 2015, 2015).
}

dilakukan oleh Pejabat Pembuat Komitmen (PPK), Haidee AR. Vigeleyn Nikijuluw. ${ }^{3}$

Dari serangkaian kasus-kasus korupsi tersebut, para sarjana sudah memberikan analisis tentang beberapa faktor penyebab terjadinya korupsi, terutama di Maluku, di antaranya faktor kebijakan, jabatan, dan pendapatan. Hal ini memperlihatkan bahwa tindakan penanganan kasus korupsi oleh lembaga-lembaga pemberantasan korupsi dan pelaksana hukum masih lemah. ${ }^{4}$ Selain itu, peran lembaga-lembaga agama masih kurang berfungsi untuk menanamkan nilai-nilai anti korupsi bagi umat. Sehingga tidak heran bila pemeluk agama terus-menerus melakukan tindakan korupsi.

Namun, pada bulan Mei 2017, beberapa sarjana menyimpulkan bahwa tindakan korupsi semakin tinggi dilakukan oleh orang Kristiani dan Muslim di Maluku, akibat dari institusi keagamaan yang kurang berperan secara optimal. Institusi keagamaan belum memiliki perencanaan secara holistik dan komprehensif dalam upaya pencegahan tindakan korupsi, sehingga siraman rohani, pendampingan kepada koruptor, tafsiran terhadap teks-teks kitab suci tentang anti korupsi kurang berlangsung secara maksimal kepada umat dan koruptor. Karena itulah kasus korupsi terus berlangsung dan dilakukan oleh baik orang Kristiani maupun orang Muslim.

Dalam upaya untuk meminimalkan tindakan korupsi tersebut, penelitian untuk pencegahan korupsi penting untuk terus dilakukan. Dinar Nurinten, $\mathrm{dkk}^{5}$ misalnya,

\footnotetext{
${ }^{3}$ Sentra Informasi dan Data Untuk Anti Korupsi, "Korupsi Di Provinsi Maluku," 2015, diakses tanggal 15 Maret 2015. http://infokorupsi.com/id/geo-korupsi.php? ac $=25 \& 1=$ maluku.

${ }^{4}$ Henky. H. Hetharia dan Samuel J. Mailoa, "Peran Institusi Keagamaan di Maluku dalam Upaya Pemberantasan Korupsi," Wawasan: Jurnal Ilmiah Agama Dan Sosial Budaya 2, no. 1 (2017): 12, doi:10.15575/jw.v2i1.921.

5 Nuriten Dinar et al., "Kearifan Lokal Sebagai Media Pendidikan Karakter Anti Korupsi pada Anak Usia Dini Melalui Strategi Dongkrak," Integritas Jurnal Antikorupsi 02, no. 1 (2016): 135.
} 
melakukan penelitian tentang penanaman karakter anti korupsi pada anak usia dini, dengan menggunakan strategi "dongkrak" yang merupakan salah satu dari kearifan lokal. Sedangkan Gusnardi, ${ }^{6}$ melakukan penelitian tentang pentingnya Mata Kuliah Anti Korupsi diajarkan kepada mahasiswa di perguruan tinggi, agar mereka memiliki pengetahuan yang memadai tentang korupsi dan anti korupsi. Sehingga diharapkan mahasiswa di kemudian hari terhindar dari peilaku korupsi. Penelitian lainnya, Laura Nuriani dkk. ${ }^{7}$ Meneliti tentang Warung Kejujuran pada SMP Keluarga Kudus. Hasil penelitian menunjukan bahwa implementasi pendidikan anti korupsi melalui warung kejujuran dikatakan masih belum berhasil, karena masih terdapat siswa dan siswi yang belum jujur ketika berbelanja di warung kejujuran.

Selain itu, perhatian terhadap persoalan perilaku korupsi juga dilakukan oleh $\mathrm{PBB}$, melalui Sidang Umum PBB pada tahun 2000 hingga menghasilkan resolusi PBB No 55/61 tahun 2000 tentang perlunya hukum internasional tentang anti korupsi secara global. Ini kemudian dilanjutkan dengan Konvensi Anti Korupsi pada tahun $2003^{8}$ dan sedangkan di ASEAN lahirlah declaration on Transnational Crime pada tahun 1997. ${ }^{9}$

Penulis menilai bahwa ternyata lembaga penegakan hukum, lembaga agama, dan lembaga pendidikan, belumlah bisa mengatasi persoalan meningkatnya korupsi. Karena itu,

\footnotetext{
${ }^{6}$ Gusnardi, "Pendidikan Anti Korupsi Di Perguruan Tinggi: Perlukah Kah? Gusnardi," Pekbis Jurnal 6, no. 2 (2013): 86-93, https://ejournal.unri.ac.id/index.php/JPEB/article/view/2155.

${ }^{7}$ Nuriani Laura Malau Gurning, Haris Mudjiman, dan Samsi Haryanto, "Implementasi Pendidikan Antikorupsi Melalui Warung Kejujuran di Smp Keluarga Kudus," Jurnal Teknologi Pendidikan dan Pembelajaran 2, no. 1 (2014): 93-102.

8 Hikmatul Akbar dan Regina Decor Carmeli, "Konvensi Anti Korupsi PBB Dan Upaya Pengembalian Aset Hasil Korupsi Ke Indonesia," 2014.

9 Ridwan Arifin, "Negara Kawasan Asia Tenggara Berdasarkan United Nations Convention Against Corruption ( UNCAC ) Dan ASEAN Mutual Legal Assistance Treaty ( AMLAT )," Jurnal Penelitian Hukum 3, no. 1 (2016): 38-39.
}

institusi keluarga mestinya bisa menjadi wadah pembentukan karakter diri seseorang untuk tidak melakukan perilaku korupsi.

Salah satu metode pembinaan anti korupsi dalam institusi keluarga adalah adanya timbal balik antara orang tua dengan anak dalam proses pendidikan dan pembinaan (reciprocal). Melalui metode ini keluarga tersebut menerapkan prinsip bahwa bukan hanya anak yang dituntut untuk tidak melakukan perilaku korupsi, melainkan juga orang tua. Karenanya, untuk mengetahui praktik reciprocal dalam pembinaan anti korupsi dalam keluarga Kristen dan Muslim di Kota Ambon tersebut, maka penting dilakukan kajian. Kajian ini menggunakan metode kualitatif dengan teknik wawancara sebagai alat pengumpulan data. Analisis data dilakukan dengan analisis kualitatif (reduksi, display, interpretasi dan kesimpulan). ${ }^{10}$ Penelitian dilakukan di Kelurahan Benteng Kecamatan Nusaniwe Ambon dan Negeri Batu Merah Kecamatan Sirimau Ambon pada bulan Juni-Juli 2016.

Kajian tentang metode timbal balik (reciprocal) dalam pembinaan anti korupsi di keluarga ini penting dilakukan mengingat realitas dewasa ini memperlihatkan bahwa metode pembinaan dalam institusi keluarga masih bersifat tradisional, seperti memberikan nasehat tanpa pendampingan yang disertai konsep yang jelas dan tanpa memberikan kesempatan kepada anak untuk menyampaikan pendapat. Dengan kata lain, metode pembinaan yang dilakukan orang tua kepada anak lebih terfokus pada orang tua, ketimbang kepada anak. Padahal, institusi keluarga, baik keluarga Kristen maupun Muslim, mesti menjadi institusi sentral untuk menanggulangi perilaku korupsi yang semakin meningkat tersebut, disertai metode pembinaan yang relevan. Sebab intensitas perjumpaan yang kontinyu dan permanen menjadi salah satu

10 Resa Dandirwalu, "Totem Ambon Manise: Membongkar Segregasi Teritorial Berbasis Agama Di Kota Ambon," Antropologi Indonesia; Indonesian Journal of Social and Cultural Anthropology 35, no. 1 (2014): 33., http://journal.ui.ac.id/index.php/jai/article/view/5511/3534. 
peluang untuk mengembangkan metode pembinaan nilai-nilai anti korupsi di dalam institusi keluarga, sehingga menghasilkan keluarga yang berperilaku anti korupsi.

\section{B. HASIL DAN PEMBAHASAN}

\section{Statistik Populasi Muslim dan Kristen di Maluku}

Berdasarkan data statistik yang dikeluarkan oleh Badan Pusat Statistik Provinsi Maluku Tahun 2016, ${ }^{11}$ populasi Muslim dan Kristen Protestan dan Katolik di Maluku yang tersebar di 11 Kabupaten/Kota, sebagai berikut:

a. Kabupaten Maluku Tenggara, jumlah Muslim 3,96; Kristen Protestan 51,06; dan Kristen Katholik 44,80

b. Kabupaten Maluku Tenggara, jumlah Muslim 29,56; Kristen Protestan 21,82; dan Kristen Katholik 47,75

c. Kabupaten MalukuTengah, jumlah Muslim 59,49; Kristen Protestan 37,00; dan Kristen Katholik 3,16

d. Kabupaten Buru, jumlah Muslim 89,47; Kristen Protestan 3,59; dan Kristen Katholik 2,01

e. Kabupaten Aru, jumlah Muslim 34,40; Kristen Protestan 53,26; dan Kristen Katholik 12,30

f. Kabupaten Seram Bagian Barat, jumlah Muslim 48,80; Kristen Protestan 49,30; dan Kristen Katholik 1,79

g. Kabupaten Seram Bagian Timur, jumlah Muslim 93,33; Kristen Protestan 2,99; dan Kristen Katholik 2,39

h. Kabupaten Maluku Barat Daya, jumlah Muslim 1,79; Kristen Protestan 96,73; dan Kristen Katholik 1,38

i. Kabupaten Buru Selatan, jumlah Muslim 68,45; Kristen Protestan 24,49; dan Kristen Katholik 1,77

j. Kota Ambon, jumlah Muslim 41,99; Kristen Protestan 50,54; dan Kristen Katholik 7,14

11 BPS, Provinsi Maluku Dalam Angka 2016 (Ambon: BPS Provinsi Maluku, 2016), 192 https://www.google.com/search?q=repetisi\&ie=utf$8 \&$ oe $=u t f-8 \&$ client $=$ firefox $-b-a b$. k. Kota Tual, jumlah Muslim 70,87; Kristen Protestan 15,94; dan Kristen Katholik 13,00

Data tersebut menunjukkan bahwa pimpinan pada daerah-daerah populasi terbanyak, maka dipimpin oleh orang yang beragama mayoritas, sehingga berpengaruh pada penempatan seseorang pada jabatan-jabatan tertentu yang bisa rentan dengan korupsi. Misalnya, pada Kota Ambon, karena mayoritas populasinya beragama Kristen, maka pemimpinnya adalah Kristen; sedangkan Kabupaten Seram Bagian Timur, karena mayoritasnya Muslim, maka dipimpin oleh Muslim. Karenanya dikaitkan dengan kasus-kasus korupsi di bagian sebelumnya, data tersebut juga menunjukkan bahwa perilaku korupsi bukanlah khas penganut agama tertentu, tetapi merupakan perilaku pejabat tertentu tanpa melihat agama yang dianutnya. Jumlah mayoritas agama populasinya tidak ada hubungannya dengan perilaku pimpinanya dalam melakukan korupsi.

\section{Selayang Pandang Kelurahan Benteng dan Negeri Batu Merah}

Berdasarkan letak geografis, Kelurahan Benteng bagian Utara berbatasan dengan Teluk Amabon, bagian Selatan berbatasan dengan Negeri Seri, bagian Timur berbatasan dengan Kelurahan Wainitu, dan bagian Barat berbatasan dengan Kelurahan Nusaniwe. Secara administrasi, Kelurahan Benteng termasuk dalam pemerintahan Kecamatan Nusaniwe. Kelurahan Benteng terdiri dari 39 RT dan 8 RW, dengan jumlah penduduk 19.009 jiwa, yang terdiri dari laki-laki (9.801 jiwa) dan perempuan (9.208 jiwa), dan rasio menurut jenis kelamin adalah 1.06. Berdasarkan jumlah penduduknya, Kelurahan Benteng termasuk jumlah penduduk terbanyak di Kecamatan Nusaniwe. Adapun dilihat dari agama, sebagian besar masyarakat di Kelurahan Benteng menganut agama Kristen Protestan. ${ }^{12}$

Berbeda dengan Kelurahan Benteng, Negeri Batu Merah secara administrasi termasuk dalam wilayah Pemerintahan Kecamatan

\footnotetext{
${ }^{12}$ BPS Kota Ambon, "Kecamatan Nusaniwe Dalam Angka 2015"(Ambon: BPS Kota Ambon, 2015).
} 
Sirimau. Sedangkan dari letak geografis, tampak bahwa bagian Utara berbatasan dengan Kali Wairuhu, bagian Selatan berbatasan dengan Kelurahan Rijali, bagian Timur berbatasan dengan Negeri Rutong, dan bagian Barat berbatasan dengan Laut Mury. Dalam sistem pemerintahannya, Negeri Batu Merah dikepalai oleh seorang Raja beserta Staf Saniri Negeri dan dibantu oleh Ketua RT dan RW. Negeri Batu Merah terdiri dari 91 RT dan 21 RW, dengan jumlah penduduk 69.400 jiwa, yang terdiri dari laki-laki (34.650 jiwa) dan perempuan (34.750 jiwa). Jadi, rasio penduduk Negeri Batu Merah berdasarkan jenis kelamin adalah 99, dengan kepadatan penduduk tiap $\mathrm{Km}^{2}$ mencapai 4163.16. Kemudian dilihat dari sisi agama, masyarakat di Negeri Batu Merah menganut agama Islam, sehingga Negeri Batu Merah sering disebut sebagai wilayah berbasis agama Islam. ${ }^{13}$

\section{Korupsi dalam Pandangan Keluarga Kristen dan Muslim Ambon}

Korupsi bisa dipahami dalam beragam konsep, tergantung perspektif yang dikedepankan. Tetapi, paling tidak terdapat empat konsep korupsi, yaitu: pertama, kebebasan dalam menentukan kebijakan; kedua, mengacaukan bahasa hukum dengan berbagai interpretasi hukum; ketiga, penyelewengan kewenangan, agar menguntungkan keuntungan diri sendiri; dan keempat, korupsi untuk kepentingan kelompok tertentu. ${ }^{14}$

Berdasarkan hasil penelitian pada keluarga Kristen di Kelurahan Benteng dan keluarga Muslim di Negeri Batu Merah tentang konsep korupsi, diperoleh gambaran bahwa pandangan mereka tentang korupsi umumnya tidak berbeda. Para informan menggambarkan konsep korupsi sebagai tindakan sadar untuk mengambil sesuatu yang bukan haknya,

13 BPS Kota Ambon, "Kecamatan Sirimau Dalam Angka 2015"(Ambon: BPS Kota AMbon, 2015).

14 Maryanto, "Pemberantasan Korupsi Sebagai Upaya Penegakan Hukum," Jurnal Ilmiah CIVIS II, no. 2 (2012): 3, http://download.portalgaruda.org/article.php article $=127938 \& \mathrm{val}=538 \&$ title $=$ PEMBERA NTASAN KORUPSI SEBAGAI UPAYA PENEGAKAN HUKUM. tindakan untuk mengambil uang negara guna kepentingan diri sendiri, dan tindakan bertentangan dengan hukum dan kehendak Tuhan. Konsep itu mengandung beberapa unsur penting di dalamnya, yaitu: unsur hukum, kebijakan, sosial, dan agama.

\section{a. Unsur Hukum}

Keluarga Kristen dan Muslim mengetahui betul bahwa tindakan korupsi sangat bertentangan dengan norma hukum karena mengambil hak yang bukan miliknya/mencuri, sehingga dapat berdampak pada sanksi hukum, yaitu dipenjarakan. Meskipun begitu, tingkat korupsi terus meningkat. Berdasarkan data kasus Tipikor di Kota Maluku, sejak tahun 20092014 terdapat 76 kasus, yang beragama Kristen 45 orang dan Islam 30 orang. ${ }^{15}$ Sedangkan data dari KPK tanggal 27 Februari 2015, menunjukkan adanya penyelidikan 19 perkara, penyidikan 8 perkara, penuntutan 4 perkara, inkracht 4 perkara, dan eksekusi 5 perkara. Sementara itu, total penanganan perkara tindak pidana korupsi dari tahun 2004-2015 adalah penyelidikan 684 perkara, penyidikan 419 perkara, penuntutan 326 perkara, inkracht 287 perkara, dan eksekusi 300 perkara.

Bertolak dari realitas tersebut, maka menurut Wakil Koordinator ICW Agus Sunaryanto, ${ }^{16}$ terdapat beberapa penyebab meningkatnya jumlah korupsi tersebut: Pertama, hukuman terhadap koruptor tidak menciptakan efek jera dan gentar, sehingga sebagian besar pelaku hanya dihukum 2 tahun oleh pengadilan dan setelah dikurangi dengan remisi serta masa tahanan. Konsekuensinya, koruptor hanya menjalani hukuman penjara singkat. Ini menunjukkan longgarnya kebijakan hukum untuk menangani koruptor; Kedua, masih kurangnya upaya pemiskinan koruptor oleh

\footnotetext{
${ }^{15}$ Henky. H. Hetharia dan Samuel J. Mailoa, "Peran Institusi Keagamaan di Maluku dalam Upaya Pemberantasan Korupsi."

16 Laksono, "Tren Korupsi Naik Lagi," 2014, diakses tanggal 15 Oktober 2016. http://nasional.kompas.com/read/2014/08/18/10085091/Tren.Korupsi. Naik.Lagi.
} 
para penegak hukum melalui penerapan pasal pencucian uang.

Berikut beberapa hasil wawancara penulis dengan informan tentang konsep korupsi yang terkait dengan unsur hukum. Pendapat yang dikemukakan oleh J. Lapatuy, bahwa "Korupsi merupakan tindakan penyelewengan tanpa menyadari adanya resiko yang akan diterimanya yaitu berujung pada hukuman penjara." $" 17$ Kemudian menurut Ibu Hj. Lia Hatala, bahwa:

Korupsi merupakan tindakan atau perbuatan yang melawan norma hukum, sehingga dapat dikatakan bahwa korupsi merupakan tindakan mencuri hak yang bukan miliknya. $^{18}$

Selain itu, menurut Rosmia, "Korupsi merupakan perbuatan yang dilakukan oleh seseorang untuk memuaskan keinginannya atau serakah, sehingga sangat bertentangan dengan norma hukum."19

Pemahaman keluarga Kristen dan Muslim tentang korupsi tersebut memberikan gambaran bahwa mereka tahu korupsi yang dilakukan merupakan tindakan melawan norma hukum, sehingga dapat berakibat pada hukuman penjara. Tetapi, hukuman penjara yang sering dialami seorang koruptor sangatlah ringan, sehingga dalam kesadaran itulah seseorang terus melakukan tindakan korupsi. Mestinya, hukuman penjara yang diberikan kepada koruptor harus mendatangkan efek jera. Sebagaimana yang disampaikan juga oleh Maryanto, bahwa sanksi hukum yang dijatuhkan kepada pelaku koruptor tidak hanya berdampak pada faktor fisik, psikis, dan hakhak politik, melainkan berdampak pula pada aspek jera, ${ }^{20}$ bahkan menurut M. Jaya Nasti, "supaya para koruptor menjadi jera, agar perilaku korupsi menjadi hilang, maka hanya

17 J. Lapatuy (Kepala Keluarga), Wawancara Oleh R. Dandirwalu, Gunung Nona Kelurahan Benteng, tanggal 12 Juni 2016.

$18 \mathrm{Hj}$. Lia Hatala (Istri), Wawancara Oleh R. Dandirwalu, Batu Merah Negeri Batu Merah, tanggal 25 Juni 2016.

${ }^{19}$ Rosmia (Istri), Wawancara Oleh R. Dandirwalu, Batu Merah Negeri Batu Merah, tanggal 28 Juni 2016.

${ }^{20}$ Maryanto, "Pemberantasan korupsi sebagai upaya penegakan hukum.” dengan menggunakan hukuman potong tangan atau hukuman mati."21

\section{b. Unsur Sosial}

Keluarga Kristen dan Muslim memiliki pengetahuan bahwa tindakan korupsi secara tidak langsung telah melanggar norma-norma atau pranata-pranata sosial yang masih dipegang dan dipraktikkan dalam masyarakat. Hal ini berpengaruh pada terciptanya kesenjangan sosial dalam masyarakat. Hak-hak yang harus diperoleh masyarakat telah dikebiri untuk kepentingan diri sendiri atau kelompok tertentu.

Bertolak dari data Kemendagri, memperlihatkan bahwa di tahun 2004-2012, terdapat 2.976 anggota DPRD Tingkat I dan DPRD Tingkat II terlibat tindakan kriminal, di mana 33,2 persen atau 349 kasus adalah korupsi. Umumnya kasus manipulasi anggaran atau mark-up biaya pengadaan barang, fasilitas dan jasa. Juga pemungutan biaya ilegal atas layanan publik, pemberian suap alias gratifikasi dan penyalahgunaan wewenang atau jabatan untuk kepentingan dan keuntungan pribadi maupun relasi. ${ }^{22}$ Akibatnya adalah tercipta kesenjangan sosial di dalam masyarakat, yaitu adanya masyarakat kaya dan masyarakat miskin. Hal itu terlihat dalam data BPS tahun 2016, bahwa "Negara Republik Indonesia memiliki tingkat kemiskinan yang masih relatif tinggi, yaitu berjumlah 28,01 juta jiwa atau 10,86 persen." 23

Berikut beberapa komentar informan terkait unsur sosial dalam konsep korupsi tersebut. Menurut Ph. Melsasail, bahwa: "Korupsi merupakan proses pengambilan hak orang

\footnotetext{
21 M. Jaya Nasti, "Masih Bisakah Korupsi Diberantas?," 2017.

${ }^{22}$ Gusnardi, "Pendidikan Anti Korupsi Di Perguruan Tinggi: Perlukah?'

${ }^{23}$ Nidia Suraya, "BPS: Jumlah Orang Miskin Di Indonesia Capai 28,01 Jiwa," diakses tanggal 15 Oktober 2016. http://www.republika.co.id/berita/ekonomi/makro/16/07/18/oai0jb383-bps-jumlah-orangmiskin-di-indonesia-capai-2801-juta. \%0A\%0A.
} 
lain yang bukan menjadi milik diri/pribadi. ${ }^{, 24}$ Sedangkan menurut F. Erupley:

Korupsi adalah tindakan mencuri uang rakyat yang dilakukan oleh pemegang kekuasaan tertinggi pada suatu instansi atau kelembagaan, baik swasta maupun pemerintah. $^{25}$

Tindakan tersebut oleh Saipul dilakukan secara sadar untuk memperkaya diri, sehingga merugikan Negara," 26 dan menurut Warni, akan tercipta kemiskinan." 27

Informasi tersebut memperlihatkan, bahwa masyarakat berhak memiliki hidup sejahtera. Hidup sejahtera dimaksud mandiri dan tidak tergantung pada perhatian dan bantuan pemerintah baik Pemerintah Pusat maupun Pemerintah Daerah. Perhatian itu diwujudkan melalui berbagai kebijakan yang mendatangkan kesejahteraan bagi masyarakat berupa pemberian bantuan di antaranya bantuan dana pendidikan dan kesehatan. Berdasarkan hasil laporan KPK di tahun 2016, tergambar bahwa antara tahun 2006-2015 terdapat 400 kasus dengan kerugian negara Rp. 1,3 triliun; sedangkan bidang kesehatan, di tahun 20012013, terdapat 100-an kasus korupsi dengan kerugian negara sekitar Rp. 594 miliar. $^{28}$ Kebijakan pemerintah tentang pemberian bantuan tersebut disalahgunakan oleh pihakpihak tertentu untuk memperkaya diri sendiri atau kelompok tertentu, sehingga masyarakat miskin sulit keluar dari kemiskinan mereka.

\section{c. Unsur Agama}

Keluarga Kristen dan Muslim sangat memahami betul bahwa tindakan korupsi

$24 \mathrm{Ph}$. Melsasail (Kepala Keluarga), Wawancara Oleh R. Dandirwalu, Gunung Nona Kelurahan Benteng, tanggal 10 Juni 2016.

${ }^{25}$ F. Erupley (Kepala Keluarga), Wawancara Oleh R. Dandirwalu, Gunung Nona Kelurahan Benteng, tanggal 17 Juni 2016.

${ }^{26}$ Saipul (Kepala Keluarga), Wawancara Oleh R. Dandirwalu, Batu Merah Negeri Batu Merah, tanggal 15 Juli 2016.

27 Warni, Wawancara Oleh R. Dandirwalu, Batu Merah Negeri Batu Merah, tanggal 18 Juli 2016.

28 Tim Penyusun Laporan Tahunan Komisi Pemberantasan Korupsi Tahun 2016, Laporan Tahunan 2016 (Jakarta: Komisi Pemberantasan Korupsi, 2017). sangat bertentangan dengan ajaran-ajaran agama. Karena setiap ajaran agama selalu menekankan aspek kejujuran, kesetiaan dan kebaikan, bukan sebaliknya menekankan aspek ketidakjujuran, ketidaksetiaan, dan keburukan bagi para pemeluknya. Dengan demikian, setiap tindakan korupsi dengan berbagai alasan apapun sangatlah bertentangan dengan kehendak Allah, dan mendatangkan dosa bagi pelakunya.

Hal ini juga diungkapkan oleh beberapa informan. Menurut A. Talakua, bahwa "Korupsi merupakan tindakan dosa karena melanggar kehendak Yesus, yang dilakukan oleh manusia tanpa menyadari resiko yang akan diterimanya di kemudian hari." 29 Selanjutnya, menurut Rahman, bahwa "Korupsi merupakan perbuatan atau tindakan yang tidak dikehendaki oleh Allah, sehingga mendatangkan dosa, baik di dunia maupun di akhirat." ${ }^{30}$ Kemudian, pendapat yang disampaikan oleh $\mathrm{Hj}$. Lia Hatala, bahwa "Korupsi merupakan tindakan atau perbuatan yang melawan Allah dan dianggap najis." 31 Pendapat informan di atas, menggambarkan bahwa perilaku korupsi bertentangan dengan ajaran-ajaran agama. Setiap agama mengajarkan umatnya untuk tidak melakukan perbuatan jahat, di antaranya adalah perilaku korupsi. Tetapi umat percaya terus melakukannya, karena lebih menekankan pada aspek keduniawiaan ketimbang aspek kerohanian. Perbuatan Korupsi menjadi suatu kewajaran dibandingkan dengan dosa yang harus diterimanya. Peranan institusi agama mestinya berfungsi untuk memperkuat iman umatnya untuk memiliki perilaku yang baik, sehingga tidak bertentangan dengan kehendak Allah. Akan tetapi, menurut Henky Hetharia dan S.J. Mailoa, institusi agama kurang berperan secara maksimal, karena pembinaan yang dilakukan masih bersifat insidental, sehingga belum

${ }^{29}$ A. Talakua (Kepala Keluarga), Wawancara Oleh R. Dandirwalu, Gunung Nona Kelurahan Benteng, tanggal 14 Juni 2016.

${ }^{30}$ Rahman (Kepala Keluarga), Wawancara Oleh R. Dandirwalu, Batu Merah Negeri Batu Merah, tanggal 21 Juni 2016.

${ }^{31}$ Hatala (Istri), Wawancara Oleh R. Dandirwalu, Batu Merah Negeri Batu Merah, tanggal 25 Juni 2016. 
terprogram secara sistematis dan komprehensif. $^{32}$

\section{Pencegahan Korupsi dalam Keluarga Kristen dan Muslim Ambon}

Metode Pembinaan dalam keluarga bagi anak-anak sejak dini menjadi titik awal untuk menghasilkan generasi baru yang anti korupsi. Karena itu, pendidikan anti korupsi dalam keluarga melalui metode timbal balik (reciprocal) bisa menjadi salah satu alternatif dalam melatih/mengajar orang Kristen dan Muslim di Ambon untuk lebih aktif, efektif dan mandiri dalam memahami dan mempraktikkan perilaku yang anti korupsi. Metode ini menuntut orang Kristen dan Muslim di Ambon untuk mengikuti empat tahapan pemahaman yaitu: pertama, tahapan menyusun pertanyaan; kedua, tahapan menjelaskan; ketiga, tahapan membuat ringkasan; dan tahap keempat, membuat prediksi.

\section{a. Tahap Menyusun Pertanyaan}

Pada tahap ini, orang tua memberikan pengetahuan atau materi kepada anak tentang topik tertentu, selanjutnya anak didampingi oleh orang tua untuk menyusun pertanyaan berdasarkan pengetahuan atau materi yang telah sampaikan. Tujuannya agar orang tua bisa mengetahui sejauh mana keingintahuan anak tentang pengetahuan atau materi yang telah disampaikan. Sehingga orang tua dapat memberikan pendampingan atau pembinaan secara kontinyu untuk meningkatkan kemampuan anak tentang pengetahuan atau materi yang disampaikan. Menurut Ph. Melsasail, pembinaan yang dilakukan dalam bentuk nasehat dan memberikan pemahaman tentang tindakan korupsi dan akibatnya kepada anakanak supaya mereka dapat mengerti bahwa tindakan korupsi itu tidak baik dan mendatangkan dosa. ${ }^{33}$

\footnotetext{
${ }^{32}$ Henky. H. Hetharia dan Samuel J. Mailoa, "Peran Institusi Keagamaan di Maluku dalam Upaya Pemberantasan Korupsi."

$33 \mathrm{Ph}$. Melsasail (Kepala Keluarga), Wawancara Oleh R. Dandirwalu, Gunung Nona Kelurahan Benteng, tanggal 10 Juni 2016.
}

Hal ini tampak pada pendapat yang dikemukakan oleh Y. Batkunde:

Saya, selalu memberikan contoh kepada anak-anak tentang tindakan anti korupsi, supaya mereka dapat meniru atau mencontoh tindakan yang saya lakukan. Karena anak-anak paling senang meniru atau mencontoh sifat dan perilaku yang dilakukan oleh orang tuanya. Selain itu, saya selalu memberikan nasehat dan pemahaman kepada anak-anak bahwa tindakan korupsi itu tidak baik karena melanggar hukum Tuhan. ${ }^{34}$

Kemudian, menurut J. Lapatuy bahwa:

Pola pembinaan yang dilakukan oleh orang tua kepada anak adalah menanamkan sifatsifat yang baik kepada mereka, seperti kejujuran, ketaatan, kesetiaan, selalu bersyukur, dan takut akan Tuhan. ${ }^{35}$

Selanjutnya, pendapat yang disampaikan oleh F. Alerbitu:

Sebagai orang tua, kami biasanya lebih menekankan berdoa kepada Tuhan untuk masa depan anak-anak, sehingga mereka bisa hidup takut Tuhan dan tidak melakukan tindakan atau perbuatan korupsi di masa yang akan datang ketika mereka telah memperoleh pekerjaan." 36

Menurut Hj. Lia Hatala, bahwa:

Pembinaan yang biasanya kami lakukan kepada anak-anak adalah mengajak mereka untuk berdoa bersama-sama, dan memberikan nasehat. Pemberian nasehat biasanya kami lakukan di meja makan."37

Begitu pula, menurut Rosmia, bahwa: Orang tua harus bertanggung jawab untuk membentuk sikap hidup anak-anak sejak dini, maka anak-anak selalu diberikan nase-

${ }^{34}$ Y. Batkunde (Kepala Keluarga), Wawancara Oleh R. Dandirwalu, Gunung Nona Kelurahan Benteng, tanggal 02 Juni 2016.

35 J. Lapatuy (Kepala Keluarga), Wawancara Oleh R. Dandirwalu, Gunung Nona Kelurahan Benteng, tanggal 12 Juni 2016.

${ }^{36}$ F. Erupley (Kepala Keluarga), Wawancara Oleh R. Dandirwalu, Gunung Nona Kelurahan Benteng, tanggal 17 Juni 2016.

${ }^{37}$ Hatala (Istri), Wawancara Oleh R. Dandirwalu, Batu Merah Negeri Batu Merah, tanggal 25 Juni 2016. 
hat dan arahan untuk hidup jujur dan takut Allah. $^{38}$

Kemudian pendapat Muna, bahwa:

Berdoa kepada Allah merupakan salah satu bentuk pembinaan yang sering dilakukan. Selain itu, kami selalu mengajak anak-anak untuk rajin ke masjid untuk mengikuti ibadah, sehingga khotbah dari ulama bisa membentuk kepribadian mereka. ${ }^{39}$

Bertolak dari hasil wawancara di atas, memperlihatkan bahwa, pada tahap menyusun pertanyaan, orang tua hanya berperan memberikan nasehat berupa pengetahuan tentang korupsi dan dampaknya kepada anak berdasarkan pengetahuan yang mereka miliki, serta nilai-nilai anti korupsi, tetapi tidak memberikan pendapampingan kepada anak-anak, supaya mereka bisa membuat pertanyaan berdasarkan nasehat yang diterima dari orang tua. Padahal, apabila orang tua melanjutkan dengan pendampingan, maka anak-anak bisa memberikan pertanyaan, maka proses dialogis antara orang tua dengan anak bisa tercipta. Karena, anak-anak juga memiliki pengetahuan awal tentang korupsi, dan kasus-kasus korupsi yang sedang berlangsung, misalnya, ketika orang tua menjelaskan tentang kasus korupsi lahan tempat pemakaman umum (TPU) Gunung Nona, Kota Ambon, senilai Rp1,2 miliar, oleh Dr. J. M. Papilaya, M.Si (Wali Kota Ambon Periode tahun 2001-2006 dan 2006-2011), maka melalui pendampingan, orang tua memberikan kesempatan kepada anak untuk bertanya seputar kasus korupsi tersebut, sehingga proses dialogpun terjadi.

\section{b. Tahap Menjelaskan}

Tahap ini, orang tua memberikan kesempatan kepada anak-anak untuk mengemukakan pendapat berdasarkan pertanyaan yang mereka susun, sehingga orang tua bisa mengevaluasi sejauhmana pemahaman mereka tentang pengetahuan atau materi yang telah diberikan oleh orang tua. Berdasarkan hasil wawancara

\footnotetext{
${ }^{38}$ Rosmia (Istri), Wawancara Oleh R. Dandirwalu, Batu Merah Negeri Batu Merah, tanggal 28 Juni 2016.

39 Muna (Istri), Wawancara Oleh R. Dandirwalu, Batu Merah Negeri Batu Merah, tanggal 10 Juli 2016.
}

di atas, tergambar bahwa orang tua tidak memberikan kesempatan kepada anak-anak untuk menyampaikan pendapat mereka karena tidak memiliki pertanyaan untuk ditanyakan. Hal inilah yang mengakibatkan proses evaluasi tidak bisa berlangsung di antara orang tua dengan anak.

\section{c. Tahap Membuat Ringkasan}

Pada tahap ini, orang tua memberikan kesempatan kepada anak untuk mengidentifikasikan aspek-aspek penting berdasarkan hasil bacaan dan pengalaman yang ditemui baik melalui media elektronik maupun media cetak. Berdasarkan hasil wawancara pada tahap pertama, tergambar bahwa pembinaan terhadap anak dalam keluarga hanya terpusat pada orang tua, sehingga pengetahuan anak tentang korupsi dan anti korupsi yang diperoleh dari hasil bacaan dan pengalaman melalui media elektronik serta media cetak tidak diperhitungkan oleh orang tua. Apabila tahap Membuat Ringkasan bisa dilakukan oleh orang tua kepada anak, maka orang tua dapat mengetahui secara jelas pemahaman dan perilaku yang akan dilakukan oleh anak di kemudian hari. Karena, anak mampu menilai dan mengidentifikasikan pengetahuan dan perilaku yang berhubungan dengan korupsi dan anti korupsi. Tujuannya agar orang tua dapat mendialogkan nilai-nilai kejujuran, dan takut Tuhan, yang dinasehatkan kepada anak dengan hasil identifikasi yang anak lakukan tersebut, sehingga proses internalisasi bisa terjadi pada orang tua dan anak. Dampaknya adalah orang tua dan anak secara bersamasama menampilkan perilaku yang anti korupsi dalam kehidupan mereka.

\section{d. Tahap Membuat Prediksi dari Informasi yang Telah Diterima}

Pada tahap ini, orang tua memberikan kesempatan kepada anak untuk menyusun pertanyaan baru berdasarkan pendapat sebelumnya, serta hasil yang ditemui melalui bacaan dan pengalaman, sehingga orang tua dan anak dapat menentukan ide, sikap dan perilaku 
ke depan. ${ }^{40}$ Tahap ini berhubungan dengan tahap sebelumnya, di mana pada tahap sebelumnya, anak tidak didampingi untuk membuat pertanyaan, anak tidak diberikan kesempatan untuk mengidentifikasikan dan menjelaskan pengetahuan dan pengalaman mereka dengan demikian, pada tahap Membuat Prediksi, anak tidak mungkin bisa menyususn pertanyaan baru, sehingga berpengaruh pada penentuan ide, sikap, dan perilaku ke depan baik oleh orang tua maupun anak.

Jelaslah bahwa metode pembinaan anti korupsi yang dilakukan oleh keluarga Kristen dan Muslim memiliki kesamaan, yaitu mempergunakan metode yang sifatnya klasik, yaitu memberikan nasehat. Kesamaan tersebut lahir dari keterbatasan pengetahuan terhadap metode-metode mutakhir yang dapat dipergunakan dalam pembinaan keluarga, khususnya tentang anti korupsi. Dengan demikian, metode timbal balik (reciprocal), bisa menjadi salah satu metode bagi keluarga Kristen dan Muslim dalam proses pembinaan keluarga, khususnya tentang anti korupsi. Sebab melalui metode tersebut, orang tua dan anak sangat berperan penting sebagai model, fasilitator, untuk proses pembimbingan dan pendampingan, sehingga orang tua dan anak memiliki kemampuan untuk mendalami dan mempraktikkan segala sesuatu yang telah diperoleh tanpa adanya paksaan.

\section{SIMPULAN}

Perilaku hidup anti korupsi merupakan dambaan setiap keluarga. Sehingga pembinaan yang berlangsung dalam keluarga secara terencana, terprogram, dan terkonsep secara baik dan komprehensif bisa dijadikan sebagai modal untuk perilaku anti korupsi dapat tercipta dalam masyarakat. Pembinaan dimaksud tidak terlepas dari metode yang dipergunakan. Karena metode yang dipergunakan kurang relevan dengan konteks, maka pembinaan yang dila-

40 Nanang Khuzaini Tatag Bagus Argikas, "Penerapan Model Pembelajaran Reciprocal Teaching Untuk Meningkatkan Pemahaman Konsep Matematika Siswa Kelas Vii Smp Negeri 2 Depok," Jurnal Mercumatika 1, no. 1 (2016): 70. kukan tidak akan berdampak positif untuk menciptakan perilaku anti korupsi dalam masyarakat.

Metode timbal balik (reciprocal) merupakan metode yang relevan dalam proses pembinaan anti korupsi yang dilakukan orang tua kepada anak. Inti dari metode tersebut adalah orang tua memberikan pengetahuan yang disertai proses pendampingan kepada anak. Sehingga anak dituntut untuk membuat pertanyaan yang dijelaskan kepada orang tua melalui proses dialog agar evaluasi terhadap hal tersebut bisa terjadi. Kemudian anak diberikan kesempatan untuk mengidentifikasikan persoalan korupsi yang sedang terjadi agar bisa membuat pertanyaan baru untuk didialogkan dengan orang tua. Sehingga menghasilkan ide/konsep bersama untuk dikembangkan dan dipraktikkan. Tetapi, metode tersebut tidak dilakukan oleh orang tua kepada anak. Orang tua masih mempergunakan nasehat sebagai metode dalam pembinaan, sehingga kurang efektif untuk dijadikan sebagai metode pembinaan anti korupsi dalam keluarga. Dengan demikian, agar perilaku anti korupsi hendak dihilangkan, maka keluarga bisa mempergunakan metode timbal balik (reciprocal) tersebut sebagai metode yang dipilih untuk proses pembinaan anti korupsi dalam keluarga.

\section{DAFTAR PUSTAKA}

Arifin, Ridwan. "Negara Kawasan Asia Tenggara Berdasarkan United Nations Convention Against Corruption UNCAC ) Dan ASEAN Mutual Legal Assistance Treaty ( AMLAT )." Jurnal Penelitian Hukum 3, no. 1 (2016): 38-39.

BPS. Provinsi Maluku Dalam Angka 2016. Ambon: BPS Provinsi Maluku, 2016.

BPS Kota Ambon. Kecamatan Nusaniwe Dalam Angka 2015, 2015.

. Kecamatan Sirimau Dalam Angka 2015, 2015.

Butt, Simon. Corruption and Law in Indonesia. London and New York: Routledge, 2012. doi:10.4324/9780203584729.

Dandirwalu, Resa. "Totem Ambon Manise: 
Membongkar Segregasi Teritorial Berbasis Agama di Kota Ambon." Antropologi Indonesia; Indonesian Journal of Social and Cultural Anthropology 35, no. 1 (2014): 33.

Dinar, Nuriten, Dewi Mulyani, Alhamuddin, dan Andalusia Neneng Permatasari. "Kearifan Lokal Sebagai Media Pendidikan Karakter Anti Korupsi pada Anak Usia Dini Melalui Strategi Dongkrak." Integritas Jurnal Antikorupsi 02, no. 1 (2016): 135.

Gusnardi. "Pendidikan Anti Korupsi Di Perguruan Tinggi: Perlukah?" Pekbis Jurnal 6, no. 2 (2013): 86-93.

Henky. H. Hetharia dan Samuel J. Mailoa. "Peran Institusi Keagamaan di Maluku dalam Upaya Pemberantasan Korupsi." Wawasan: Jurnal Ilmiah Agama Dan Sosial Budaya 2, no. 1 (2017): 12. doi:10.15575/jw.v2i1.921.

Hikmatul Akbar, dan Regina Decor Carmeli. "Konvensi Anti Korupsi PBB Dan Upaya Pengembalian Aset Hasil Korupsi Ke Indonesia," 2014.

Korupsi, Sentra Informasi dan Data Untuk Anti. "Korupsi Di Provinsi Maluku." diakses tanggal 15 Maret 2015, 2015.

Laksono. "Tren Korupsi Naik Lagi." diakses tanggal 15 Oktober 2016, 2014.

M. Jaya Nasti. "Masih Bisakah Korupsi Diberantas?," 2017.

Maryanto. "Pemberantasan korupsi sebagai upaya penegakan hukum." Jurnal Ilmiah CIVIS II, no. 2 (2012): 3.

Nidia Suraya. "BPS: Jumlah Orang Miskin Di Indonesia Capai 28,01 Jiwa." diakses tanggal 15 Oktober 2016, 2016.

Nuriani Laura Malau Gurning, Haris Mudjiman, dan Samsi Haryanto. "Implementasi Pendidikan Antikorupsi Melalui Warung Kejujuran di Smp Keluarga Kudus." Jurnal Teknologi Pendidikan dan Pembelajaran 2, no. 1 (2014): 93-102.

Tatag Bagus Argikas, Nanang Khuzaini. "Penerapan Model Pembelajaran
Reciprocal Teaching Untuk Meningkatkan Pemahaman Konsep Matematika Siswa Kelas Vii Smp Negeri 2 Depok." Jurnal Mercumatika 1, no. 1 (2016): 70.

Tim Penyusun Laporan Tahunan Komisi Pemberantasan Korupsi Tahun 2016. Laporan Tahunan 2016. Jakarta: Komisi Pemberantasan Korupsi, 2017.

\section{WAWANCARA}

J. Lapatuy, J. (Kepala Keluarga). Wawancara Oleh R. Dandirwalu. Gunung Nona Kelurahan Benteng. Tanggal 12 Juni 2016.

Hatala, Lia (Istri). Wawancara Oleh R. Dandirwalu. Batu Merah Negeri Batu Merah. Tanggal 25 Juni 2016.

Rosmia (Istri). Wawancara Oleh R. Dandirwalu. Batu Merah Negeri Batu Merah. Tanggal 28 Juni 2016.

$\mathrm{Ph}$. Melsasail (Kepala Keluarga). Wawancara Oleh R. Dandirwalu. Gunung Nona Kelurahan Benteng. Tanggal 10 Juni 2016.

Erupley, F. (Kepala Keluarga). Wawancara Oleh R. Dandirwalu. Gunung Nona Kelurahan Benteng. Tanggal 17 Juni 2016.

Saipul (Kepala Keluarga). Wawancara Oleh R. Dandirwalu. Batu Merah Negeri Batu Merah. Tanggal 15 Juli 2016.

Warni. Wawancara Oleh R. Dandirwalu. Batu Merah Negeri Batu Merah. Tanggal 18 Juli 2016.

Talakua, A. (Kepala Keluarga). Wawancara Oleh R. Dandirwalu. Gunung Nona Kelurahan Benteng. Tanggal 14 Juni 2016.

Rahman (Kepala Keluarga). Wawancara Oleh R. Dandirwalu. Batu Merah Negeri Batu Merah. Tanggal 21 Juni 2016.

Hatala (Istri). Wawancara Oleh R. Dandirwalu. Batu Merah Negeri Batu Merah. Tanggal 25 Juni 2016.

Batkunde,Y. (Kepala Keluarga). Wawancara Oleh R. Dandirwalu. Gunung Nona Kelurahan Benteng. Tanggal 02 Juni 2016.

Muna (Istri). Wawancara Oleh R. Dandirwalu. Batu Merah Negeri Batu Merah. Tanggal 10 Juli 2016. 